ISSN(Printed): $1997-2490 \quad$ ISSN(Online): $2411-3514$
DOI: /10.29350/jops.
Al-0adisigah Journal of Pure Science
http://qu.edu.iq/iournalsc/index.php/IOPS

\title{
Effect of the type of organic matter and a source of phosphorous on the growth, yield of corn (Zea mays L.) under different levels from phosphorous in gypsum soil
}

\section{Authors Name \\ a. Noor AL-Dean Mohammed Muhawish \\ b. Nashmi Ahmed Hilal \\ Article History \\ Received on: 28/6/2021 \\ Revised on: 8/8/2021 \\ Accepted on: 13/8/2021 \\ Keywords: \\ organic matter,phosphorus, corn , gypsum soil.}

DOI: https://doi.org/10.29350/

jops.2021.26. 4.1434

\begin{abstract}
A biological experiment was carried out for the purpose of knowing the effect of the type of organic matter, source and level of phosphorous on the growth and yield of corn (Zea mays L.) in gypsum soil. The experiment was carried out in one of the agricultural fields in Salah al-Din Governorate / Al-Alam district in the year 2019. The study included three factors (type of organic fertilizer, phosphorous source and phosphorous level). The factor included the type of organic fertilizer (not adding $\mathrm{Z}$, compost $\mathrm{K}$ and sheep waste $\mathrm{S}$ ), while the second factor included the source of phosphate fertilizer (Triple super phosphate $\mathrm{T}$, diammonium phosphate $\mathrm{D}$ ), and the third factor included phosphorous levels $\left(0,90,180\right.$ and 270) $\mathrm{kg} \mathrm{P} \mathrm{ha}^{-1}$. The experiment was carried out in three replications according to a randomized complete block design (RCBD). Sheep manure outperformed compost in all growth and yield traits, and diammonium phosphate fertilizer outperformed Triple le super phosphate, and the level (270) $\mathrm{kg} \mathrm{P} \mathrm{ha}^{-1}$ was superior to the rest of the addition levels in all growth and yield traits. The interaction between sheep manure and diammonium phosphate fertilizer at the level of addition (270) $\mathrm{kg} \mathrm{P} \mathrm{ha}^{-1}$ gave the highest average in the dry weight of the vegetative mass after 45 and 75 days of planting, it reached (55.50 and 130.81) gm plant $^{-1}$, respectively, Chlorophyll content in leaves (52.80) SPAD and grain yield reached (8119) $\mathrm{kg} \mathrm{ha}^{-1}$.
\end{abstract}




\section{Introduction}

The lands of dry and semi-arid regions, including Iraq, are characterized as calcareous lands, and the amount of nutrients ready for the plant in these soils are few or low due to their high content of calcium carbonate and high $\mathrm{pH}$. Gypsiferous soils are also spread in Iraq, which constitute more than $20 \%$ of the area of Iraq and extend from southern Sinjar to southern Iraq and are concentrated in the flats of the Tigris and Euphrates rivers, and some of them are located in the Western Desert [1]. The elements necessary for plant growth, so the deficiency must be compensated by adding fertilizers, especially phosphorus fertilizers, as phosphorous is the key to life because of its participation in most of the processes that take place inside plant cells, and one of the most important of these processes is the decomposition of carbohydrates and materials resulting from the photosynthesis process to liberate Energy required for vital processes. Therefore, the availability of phosphorus in the soil and in sufficient quantities is important for plant growth [23], as it helps in plant cell division and participates in the transfer of genetic traits through DNA.

Organic fertilizers are an important way to preserve the nutrients needed for plant growth. When decomposing, they help increase the concentration of nutrients, improve soil construction and aeration, facilitate root penetration and their ability to retain water, and reduce the loss of nutrients as they reduce soil erosion, increase soil warming, and encourage microbial activity. and plant disease resistance [6].

Through the use of organic and mineral fertilizers together, it is possible to achieve high productivity and better quality of corn than using each of them alone. Therefore, it is necessary to maintain soil fertility and increase its productivity by following effective means to address a number of problems of these soils by adding chemical and organic fertilizers and following scientific methods in managing Soil to raise the efficiency of nutrient absorption in a balanced manner and in line with the need of the plant to meet its requirements of these elements [11]

corn (Zea maysL.) is considered one of the important strategic and economic crops in the world and in Iraq and is widely cultivated in several regions of the country. This crop occupies the first place in the production of grain yield per unit area. Its grain is characterized by its high amounts of pro- vitamin A and twenty times more than what wheat grains contain. Its importance is equal to the importance of soybean seeds in providing essential amino acids. And corn is one of the crops that stresses the soil and responds to the added chemical fertilizers due to the soil's lack of organic matter and basic and micro nutrients. Therefore, multiple methods and means have been followed to provide and prepare nutrients for the corn crop without negatively affecting the soil environment and the quantity and quality of the crop.

It is known that gypsum soils suffer from problems with the aforementioned characteristics. Therefore, the current study aims to know the effect of the source of 
organic matter and phosphorous on the growth and yield of corn under different levels of phosphorus.

\section{Materials and methods}

\subsection{Agriculture soil analysis}

Random samples were taken from the field soil before cultivation process at a depth of 0-30 cm, then mixed homogeneously, air-dried and ground, then passed through a sieve with a diameter of $2 \mathrm{~mm}$ to estimate some of its physical and chemical properties in the laboratory of the Department of Soil Sciences and Water Resources of the College of Agriculture, Table 1. The volume ratios of soil separations of sand, silt and clay were estimated using the hydrometer method described by [4]. The bulk density of paraffin wax was estimated according to [4] method. The $\mathrm{pH}$ and electrical conductivity of the soil extract were measured (1:1) according to the method mentioned in [7] the positive ion exchange capacity (CEC) was estimated by the method of sodium acetate and ammonium acetate described in [20], while carbonate minerals ( $\mathrm{CaCO} 3)$ was estimated by the gravimetric method mentioned in [22]. Gypsum was estimated (CaSO4. 2H2O) by dilution method, as distilled water was used in the extraction in a solution containing acetic acid and acetone to precipitate gypsum and according to the method described in [9]. The organic matter was estimated by wet digestion with sulfuric and phosphoric acid with ammoniac ferrous sulfate. According to the method of (Walkely and Black) mentioned in [7], the dissolved positive and negative ions were estimated in a soil extract (1:1) as sodium and potassium were estimated using a flame photometer. Calcium and magnesium were determined by stroking method $(0.01 \mathrm{~N})$, while chloride was measured by scaling With silver nitrate solution $(1.0 \mathrm{~N})$. The sulfates were determined by precipitation method in the form of barium sulfate, while the carbonates and bicarbonates were estimated by scaling with sulfuric acid [22]. The prepared nitrogen was estimated by potassium chloride $(2 \mathrm{M} \mathrm{KCl})$ in a steam distillation device (Mico-Kjeldahl) according to Method [5] The available phosphorous in the soil was estimated by extracting the soil with a solution of sodium bicarbonate $(0.5 \mathrm{M} \mathrm{NaHCO})$ at $\mathrm{pH} 8.5$. The blue color was developed using a solution of $\mathrm{M}$. The lipids of ammonium and ascorbic acid were measured using a spectrophotometer at a wavelength of $840 \mathrm{~nm}$ as mentioned in [18], the dissolved phosphorous was estimated by extracting it with distilled water at a ratio (1 soil: 10 water) using a Spectrophotometer, and the ready potassium extracted with ammonium acetate solution was estimated according to method [21]. 
Table 1- Some physical and chemical characteristics of used soil

\begin{tabular}{|c|c|c|}
\hline Property & Unit & Value \\
\hline Sand & \multirow{3}{*}{$\mathrm{g} \mathrm{kg}^{-1}$} & 451 \\
\hline Silt & & 313 \\
\hline Clay & & 236 \\
\hline Texture & & Sandy clay loam \\
\hline Bulk density & $\mathrm{Mg} \mathrm{m}^{-3}$ & 1.353 \\
\hline pH & 1 & 7.63 \\
\hline EC & $\mathrm{dS} \mathrm{m}^{-1}$ & 2.41 \\
\hline CEC & cmole $^{+} \mathrm{kg}^{-1}$ & 17.07 \\
\hline S.O.M & \multirow{3}{*}{$\mathrm{g} \mathrm{Kg}^{-1}$} & 8.20 \\
\hline $\mathrm{CaSO}_{4} \cdot 2 \mathrm{H}_{2} \mathrm{O}$ & & 123 \\
\hline carbonate minerals & & 202.57 \\
\hline Available N & \multirow{6}{*}{$\mathrm{mg} \mathrm{Kg}^{-1}$ soi } & 23.50 \\
\hline Available $\mathrm{K}$ & & 117 \\
\hline Available $\mathrm{P}$ & & 6.741 \\
\hline Soluble P & & 0.161 \\
\hline Total P & & 709.21 \\
\hline Organic $\mathrm{P}$ & & 89.14 \\
\hline \multicolumn{3}{|l|}{ Soluble ions } \\
\hline $\mathrm{Na}^{+}$ & \multirow{8}{*}{ Mlmol L ${ }^{-1}$} & 1.39 \\
\hline $\mathbf{K}^{+}$ & & 0.55 \\
\hline $\mathrm{Ca}^{2+}$ & & 11.03 \\
\hline $\mathrm{Mg}^{2+}$ & & 6.22 \\
\hline $\mathrm{CL}^{-}$ & & 1.83 \\
\hline $\mathrm{CO}_{3}=$ & & Nil \\
\hline $\mathrm{HCO}_{3}^{-}$ & & 1.76 \\
\hline $\mathrm{SO}_{4}{ }^{=}$ & & 15.41 \\
\hline
\end{tabular}

\section{2. organic waste}

Two types of organic waste were selected, which are animal waste (sheep), which were collected from one of the sheep fields in the Al-Alam district and were air-dried, then crushed and passed through a sieve with holes diameter of $2 \mathrm{~mm}$. As for the residues of the corn cobs (the calcareous corn cob without grain) obtained from the 
Mesopotamian Company (the silo of corn in the Al-Alam area). The korean was air dried, and impurities, rock pieces and gravel were removed from it, then it was cut and crushed by an electric grinder and prepared for the decomposition process. $0.5 \% \mathrm{P}$ of Triple le super phosphate fertilizer $(20 \% \mathrm{P})$ with the addition of decomposed poultry residues and fertile soil with a percentage of not more than $5 \%$, after working in suspension, and continuously moistening and stirring every 3 to 4 days until a degree of decomposition is reached Then, it is possible to diagnose the substance as to its severity, after which the decomposing organic waste is spread out to air-dry for a period of three days. The process lasted for 90 days, starting from 23/12/2018 to 23/4/2019. Then a sample of it was taken for the purpose of conducting some chemical analyzes on it as shown in Table (2), after which it was filled in plastic bags and kept until use.

Field experience: The study included three factors:

-Type of organic material (Not adding organic fertilizer, sheep waste and compost).

-source of phosphorous (Triple le Super Phosphate TSP, Diammonium Phosphate DAP).

-Phosphorous levels $\left(0,90,180\right.$ and 270) $\mathrm{kg} \mathrm{P} \mathrm{ha}^{-1}$.

Table 2- Some characteristics of organic fertilizer

\begin{tabular}{|c|r|r|r|r|r|r|r|r|}
\hline Property & PH & EC & $\begin{array}{r}\text { N } \\
\%\end{array}$ & $\begin{array}{r}\text { P } \\
\%\end{array}$ & $\begin{array}{r}\text { K } \\
\%\end{array}$ & $\begin{array}{r}\text { C } \\
\%\end{array}$ & C/N & C/P \\
$\begin{array}{c}\text { Organic } \\
\text { matter }\end{array}$ & ds m $^{-1}$ & & & & & & \\
\hline $\begin{array}{c}\text { Sheep } \\
\text { Manure }\end{array}$ & 7.69 & 8.37 & 3.42 & 0.620 & 0.85 & 44.05 & 12.88 & 71.05 \\
\hline Compost & 7.84 & 4.82 & 3.10 & 0.410 & 0.55 & 55.74 & 17.98 & 135.95 \\
\hline
\end{tabular}

\subsection{Agricultural experience}

The process of plowing, smoothing and leveling was carried out by means of the disc harrows, then the field was divided into three design sectors (RCBD), the distance between one sector and another was (2) $\mathrm{mm}$. (9) $\mathrm{m}^{2}$, leaving a distance of (1) $\mathrm{m}$ between one board and another, so the number of experimental units is 72 experimental units. The corn kernels, variety DKC1989 (American imported), were planted on 7/17/2019 in the hollow at a rate of (2-3) grains per hole and at a depth of $(3-5) \mathrm{cm}$ in the form of lines. And the number of lines is 4 lines in each panel and in each line 12 plants after the slipper (one plant in the hole) and the patching up to one plant in each hole. Urea $46 \%$ fertilizer was used as a source of nitrogen and was added 
in fixed quantities $320 \mathrm{~kg} \mathrm{~N} \mathrm{H1}$ - for all treatments as it was added in two batches, the first at planting and the second after 40 days of germination ( The amount of nitrogen in the DAP fertilizer was taken into account to ensure an equal amount of nitrogen for all treatments. Phosphate fertilizers (TSP and DAP) were added by spreading and mixing them with the soil. Also, organic fertilizers were added at a rate of (60 tons ha1) by scattering for each plate and mixing it with the soil by (the squeegee) and then by hand knurling. Weeding of the bushes was carried out manually. As for the control of the corn stalk insect, the stem borer Semia gilica L, it was controlled with diazinon. $10 \%$ granular at a rate of $6 \mathrm{~kg} \mathrm{ha}^{-1}$ after (20 and 40) days of germination in the growing tops of the stem [2], the service and irrigation operations continued until the end of the season on November 19, 2019 after 121 days of planting. The yield of ten plants was taken from each experimental unit and then divided by their number to represent the yield of the individual plant with weight adjustment based on a humidity of $15.5 \%$.

\subsection{Studied traits}

\subsubsection{Dry weight of the vegetative complex of the first and second cuttings (gm plant $^{-1}$ )}

The dry weight of the vegetative group (stem and leaves) was estimated for each period (the first cut was taken after 45 days of planting, and the second cut was taken after 75 days of planting), as the samples were placed in perforated paper bags and then entered into the electric oven at a temperature of $70{ }^{\circ} \mathrm{C}$ for a period of time. 72 hours and was weighed several times until the weight was stabilized using the sensitive balance.

\subsubsection{Chlorophyll content (SPAD)}

The chlorophyll content was measured in the ear of five plants from each experimental unit from the midlines randomly. The chlorophyll was measured in the field by a chorophyl meter type 502-SPAD, then three readings were taken for each leaf and the average was taken for all leaves for each experimental unit.

\subsubsection{Grain yield $\left(\mathrm{kg} \mathrm{ha}^{-1}\right)$}

The yield of ten plants was taken from each experimental unit and then divided by their number to represent the yield of the individual plant with weight adjustment based on a humidity of $15.5 \%$ :

Grain yield $\left(\mathbf{k g ~ h a} \mathbf{~}^{-\mathbf{1}}\right)=$ individual plant yield $*$ plant density

A Randomized Complete Block Design (R.C.B.D) was used. The averages of the results were analyzed statistically by using the SAS statistical program, and the Duncan test was used to compare the averages at a probability level of 0.05 . 


\section{Results and discussion}

\subsection{Dry matter yield of the shoot after 45 days of planting (gm plant ${ }^{-1}$ )}

Table (3) shows that corn plants responded significantly to the addition of phosphate fertilizer in this gypsum soil with a low content of ready phosphorus $(6,741)$ mg kg-1 (Table 1), and raising the level of phosphate fertilizer led to a significant increase in the dry matter yield. For corn, it amounted to $(22.4,37.25$ and 43.44)\%, with values of $\left(45.89,41.55\right.$ and 53.76) $\mathrm{gm} \mathrm{plant}^{-1}$ to the levels of addition (90, 180 and 270) kg Pha-1, respectively, compared to the treatment of no addition, which gave a yield of (37.48) gm Plant $^{-1}$, the reason may be that the addition of phosphate fertilizer led to an increase in the availability of phosphorus in the soil, which led to the formation of a good efficient root system capable of absorbing other nutrients and transferring them to the upper parts, which was positively reflected on the dry weight of the plant. It is noticed from the data of Table (3) that the weight of the dry matter was higher in the treatments of DAP fertilizer compared to the treatments of Triple le super phosphate fertilizer. DAP fertilizer has a higher or higher solubility than TSP fertilizer, which led to a greater provision of phosphorous during the early stages of the plant's life. It reduces the $\mathrm{pH}$ of the soil and increases the solubility of some phosphorous compounds in the soil and its readiness for plants, in addition to increasing the readiness of some other nutrients and their absorption by the crop and then increasing the yield of dry matter. Growth and production indicators of the yield by adding multiple sources of phosphate fertilizer, and the superiority of the phosphate fertilizer source that is more soluble and acidic in the soil than other sources.

Table (3) indicates that the addition of sheep and compost residues gave a dry yield of (49.00 and 47.39) gm plant ${ }^{-1}$, respectively, superior to the non-addition treatment, which gave an average of (45.05) gm plant ${ }^{-1}$, and the reason for this is attributed to the role of organic fertilization in Increasing soil fertility and the availability of nutrients in it, as well as supplying the soil with nutrients such as N, P, K (Table 2) and improving the physical properties of the soil, which leads to an increase in the penetration of roots into the soil and an increase in the efficiency of absorption of water and nutrients by the plant, as well as Increasing the ability to retain moisture in the soil, which was positively reflected in the increase in the yield of dry matter, and this is consistent with what was indicated by [26]. The superiority of sheep residues over compost is also attributed to the fact that it contains more nutrients than compost, and from another degree it secretes organic acids. Most of the compost is produced, and these acids lower the $\mathrm{pH}$ and increase the readiness of nutrients. The results of the binary interaction between the source and level of phosphate fertilizer appear in favor of treatment DP3, which gave a yield of (54.42) gm plant $^{-1}$, and the comparison treatments TP0 and DP0 gave a yield of (37.33 and 37.63) gm plant ${ }^{-1}$, respectively. The interaction between the source of organic fertilizer and the level of phosphorous showed significant differences between the treatments, as the treatment SP3 gave the highest dry yield amounted to (54.39) gm plant ${ }^{-1}$ ), which did not differ significantly from the treatment KP3, which gave a yield of (54.22) gm plant ${ }^{-1}$, and the treatment 
Table 3 - Effect of phosphorous source and organic fertilizer on dry matter yield for a period of 45 days $\left(\mathrm{gm} \mathrm{plant}^{-1}\right)$ under different levels of phosphorous

\begin{tabular}{|c|c|c|c|c|c|c|}
\hline \multirow{2}{*}{$\begin{array}{c}\text { Type } \\
\text { organic } \\
\text { fertilizer } \\
\text { M }\end{array}$} & \multirow{2}{*}{$\begin{array}{c}\text { source of } \\
\text { phosphat } \\
\mathrm{e} \\
\text { fertilizer } \\
\mathrm{T}\end{array}$} & \multicolumn{4}{|c|}{$\begin{array}{c}\text { Phosphor rate }\left(\mathrm{Kg} \mathrm{ha}^{-1}\right) \\
\mathrm{P}\end{array}$} & \multirow{2}{*}{ MT } \\
\hline & & $\mathrm{P}_{0}$ & $\mathrm{P}_{1}$ & $\mathrm{P}_{2}$ & $\mathrm{P}_{3}$ & \\
\hline \multirow[t]{2}{*}{$\mathrm{Z}$} & $\mathbf{T}$ & 33.301 & $42.69 \mathrm{ghi}$ & $48.00 \mathrm{cdef}$ & $51.55 \mathrm{abcd}$ & $43.86 \mathrm{c}$ \\
\hline & D & $34.55 \mathrm{lk}$ & $45.89 \mathrm{efg}$ & 50.65abcde & $53.77 \mathrm{ab}$ & $46.215 \mathrm{~b}$ \\
\hline \multirow[t]{2}{*}{$\mathrm{S}$} & $\mathbf{T}$ & 40.88hij & 46.71defg & $51.70 \mathrm{abc}$ & $53.27 \mathrm{ab}$ & $48.14 \mathrm{ab}$ \\
\hline & D & $40.09 \mathrm{ij}$ & $49.21 \mathrm{bcdef}$ & $54.57 \mathrm{a}$ & $55.50 \mathrm{a}$ & $49.84 \mathrm{a}$ \\
\hline \multirow{2}{*}{$\mathrm{K}$} & $\mathbf{T}$ & $37.80 \mathrm{jkl}$ & $44.84 \mathrm{fgh}$ & $51.33 \mathrm{abcd}$ & $54.45 \mathrm{a}$ & $47.11 \mathrm{ab}$ \\
\hline & D & $38.26 \mathrm{ijk}$ & $46.00 \mathrm{efg}$ & $52.41 \mathrm{abc}$ & $53.99 \mathrm{ab}$ & $47.67 \mathrm{~b}$ \\
\hline \multirow{3}{*}{\begin{tabular}{|l} 
\\
$P$
\end{tabular}} & & & & & & Average $\mathrm{T}$ \\
\hline & $\mathbf{T}$ & $37.33 \mathrm{~d}$ & $44.75 \mathrm{c}$ & $50.34 \mathrm{~b}$ & $53.09 \mathrm{a}$ & $46.38 \mathrm{~B}$ \\
\hline & D & $37.63 \mathrm{~d}$ & $47.03 \mathrm{c}$ & $52.54 \mathrm{ab}$ & $54.42 \mathrm{a}$ & $47.91 \mathrm{~A}$ \\
\hline & & & & & & Average $\mathrm{M}$ \\
\hline \multirow[b]{3}{*}{ MP } & $\mathrm{Z}$ & $33.93 \mathrm{~g}$ & $44.29 \mathrm{e}$ & $49.33 b c$ & $52.66 \mathrm{a}$ & $45.05 \mathrm{C}$ \\
\hline & $\mathrm{S}$ & $40.49 \mathrm{f}$ & $47.96 \mathrm{~cd}$ & $53.14 \mathrm{a}$ & $54.39 \mathrm{a}$ & $49.00 \mathrm{~A}$ \\
\hline & $\mathrm{K}$ & $38.03 \mathrm{f}$ & $45.42 \mathrm{de}$ & $51.87 \mathrm{ab}$ & $54.22 \mathrm{a}$ & $47.39 \mathrm{~B}$ \\
\hline \multicolumn{2}{|c|}{ Average $\mathrm{P}$} & $37.48 \mathrm{D}$ & $51.44 \mathrm{~B}$ & $45.89 \mathrm{C}$ & $53.76 \mathrm{~A}$ & \\
\hline \multicolumn{3}{|c|}{$\begin{array}{l}\text { T: Triple super phosphate } \\
\mathrm{D}: \text { Di- Ammonium phosphate }\end{array}$} & $\begin{array}{l}\mathrm{P}_{0}: 0 \mathrm{kgPha}^{-1} \\
\mathrm{P}_{1}: 90 \mathrm{kgP} \mathrm{ha}^{-1} \\
\mathrm{P}_{2}: 180 \mathrm{Kg} \mathrm{P} \mathrm{ha}^{-1} \\
\mathrm{P}_{3}: 270 \mathrm{Kg} \mathrm{P} \mathrm{ha}^{-1}\end{array}$ & $\begin{array}{l}Z: N \\
S: s h \\
K: c\end{array}$ & $\begin{array}{l}\text { eep manure } \\
\text { expost }\end{array}$ & nic fertilizer \\
\hline $\mathrm{N}$ & & n & $\begin{array}{l}\text { ilar lett } \\
\text { accord }\end{array}$ & $\begin{array}{l}\text { ignific } \\
\text { test }\end{array}$ & ifference & veen them \\
\hline
\end{tabular}

ZP0 (without Addition of organic fertilizer and phosphate) the lowest average in this interaction was (33.93) $\mathrm{gm} \mathrm{plant}^{-1}$. The results of Table (2) indicate that the interaction between the source of organic fertilizer and the source of phosphorous was in favor of 
the SD treatment, which gave the highest mean of (49.84) mg plant ${ }^{-1}$, superior to all treatments in this interaction except for the KD treatment, and the ZT treatment gave the lowest average of (43.86) $\mathrm{gm} \mathrm{plant}^{-1}$. The interaction between the three study factors showed significant differences between some treatments if the interaction treatment SDP3 gave the highest average of (55.50) $\mathrm{gm} \mathrm{plant}^{-1}$, which did not differ significantly from the interaction treatments SDP2, ZDP3, ZTP3, STP3, KDP3, KTP3 and KDP2, and the comparison treatments ZTP0 and ZDP0 gave The lowest average was (33.30 and 34.35) gm plant $^{-1}$, respectively.

\subsection{Dry matter yield of the plant after 75 days of planting (gm Plant ${ }^{-1}$ )}

Through the results of Table (4), we note that the dry weight of the plant was affected by the level and source of phosphate, as well as by the type of organic waste, and the differences were significant as the level (P3) was given. The highest yield of dry plant was (119.02) gm plant ${ }^{-1}$, while treatments (P0 and P1 and P2) averaged (85.30, 101.71 and 112.953) $\mathrm{gm} \mathrm{plant}^{-1}$, respectively. This increase is attributed to the increase in the availability of phosphorous in the soil and then the increase in dry weight. Phosphorous also plays a vital role in building an effective root group, which increases the efficiency of water and nutrients absorption in the plant, which is positively reflected in increasing the leaf area and increasing the manufacture of carbohydrates and protein substances that are distributed in the various plant tissues to increase the dry weight of the plant [14]. The results of Table (4) showed that the phosphate source had a significant effect on the value of the dry weight of the plant after 75 days of planting, as the DAP fertilizer outperformed the TSP fertilizer and gave an average of (107.15) $\mathrm{gm} \mathrm{plant}^{-1}$, and Triple le superphosphate gave an average of (102.34) ) gm plant ${ }^{-1}$.The difference between the sources in the production of dry matter for the crop is due to the difference in its effect on the $\mathrm{pH}$ of the soil, where the diammonium phosphate fertilizer is characterized by its acidic effect, which reduces the soil $\mathrm{pH}$ and increases the solubility of some phosphorous compounds in the soil and its readiness for plants. from the availability of certain nutrients. Table (4) shows that adding sheep residue and manure gave an increase in plant dry weight (10.07 and $4.62) \%$, respectively, compared to the no-addition treatments, which gave an average of (99.86) $\mathrm{gm} \mathrm{plant}^{-1}$, and the reason for this increase is due to the ability of organic fertilizers to continuously provide the necessary nutrients and increase their willingness to absorb the plant, which was positively reflected in building an effective root system that increased the absorption of water and nutrients in the plant and increased the output of photosynthesis and thus increased growth The vegetative nature of the plant in general, which is represented by the increase in the area of the plant and leaves and the increase in the manufacture of carbohydrates and proteins that are distributed in the tissue plant to increase its dry weight [15] that the addition of organic fertilizer increased the dry weight of corn. We also note the superiority of sheep waste over compost due to the fact that sheep waste contains more nutrients than compost (Table 2), which is reflected in the increase in the dry weight of the plant. The results of the binary interaction between the source and level of phosphate fertilizer 
Table 4 - Effect of phosphorous source and organic fertilizer on dry matter yield for a period of 75 days $\left(\mathrm{gm} \mathrm{plant}^{-1}\right)$ under different levels of phosphorous

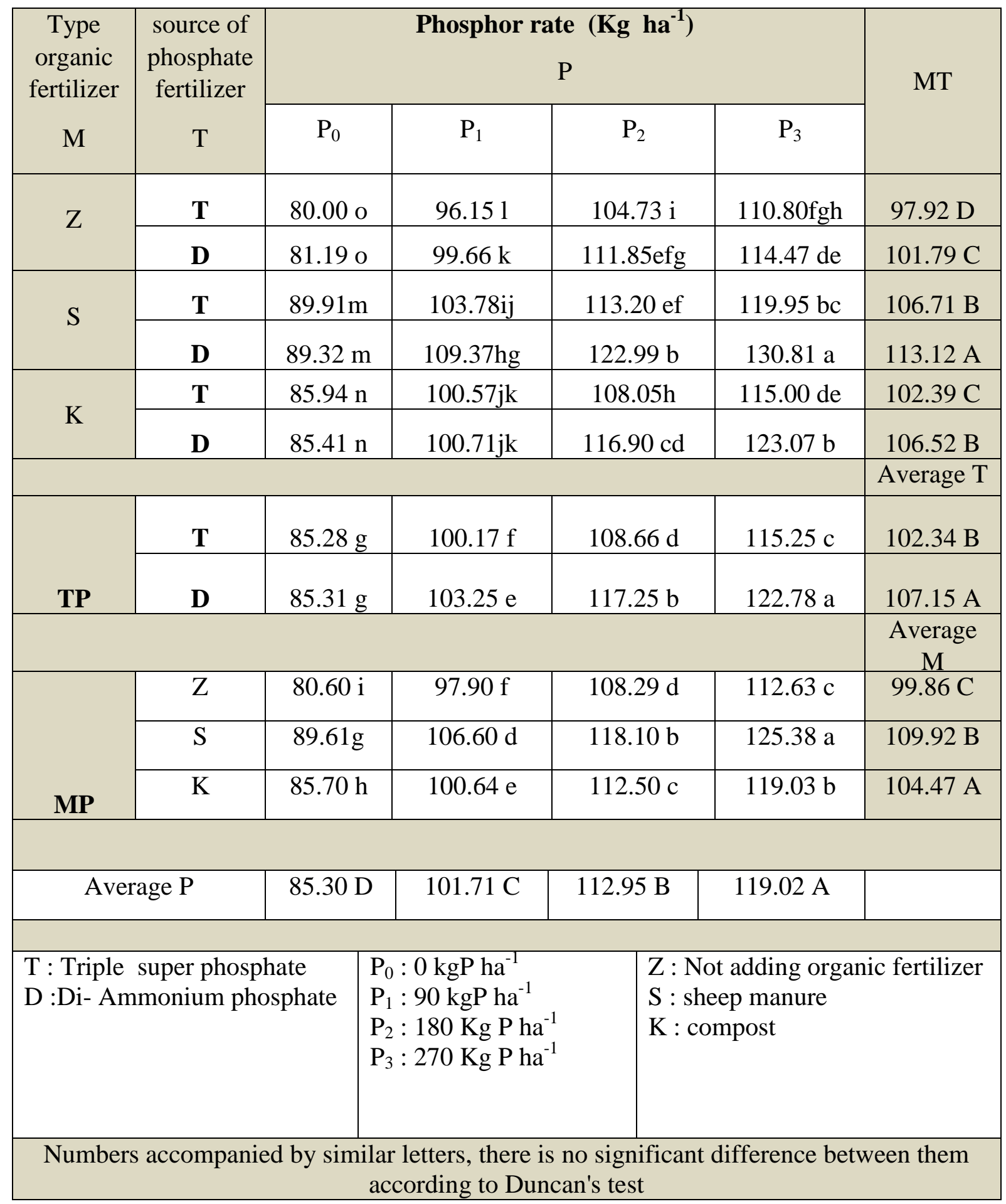

were in favor of treatment DP3, which gave a yield of (122.78) gm plant ${ }^{-1}$, and the comparison treatments TP0 and DP0 gave a yield of (85.28 and 85.31) gm plant ${ }^{-1}$, respectively, and from the observations made by these interactions All levels of DAP fertilizer are superior to those of Triple le Super Phosphate fertilizer. The interaction between the source of organic fertilizer and the level of phosphorous showed 
significant differences between the treatments, as the treatment SP3 gave the highest dry yield of (125.38) gm plant ${ }^{-1}$, which was significantly superior to all treatments in this interaction, and the treatment ZP0 (without adding organic fertilizer and phosphate) gave the lowest average in This overlap was (80.60) gm plant ${ }^{-1}$. The results of Table (4) indicate that the interaction between the source of organic fertilizer and the source of phosphorous was in favor of the SD treatment, which gave the highest average of (113.12) gm plant ${ }^{-1}$, superior to all treatments in, and the treatment ZT gave the lowest average in this interaction reached $\left(97.92 \mathrm{gm} \mathrm{plant}^{-1}\right.$. The interaction between the three study factors showed significant differences between some treatments if the interaction treatment SDP3 gave the highest average amounted to (130.81) gm plant $^{-1}$, which was significantly superior to all treatments in this interaction, and the comparison treatments ZTP0 and ZDP0 gave the lowest average amounted to $\left(80.00\right.$ and $81.19 \mathrm{gm} \mathrm{plant}^{-1}$, respectively.

\subsection{Concentration of chlorophyll in leaves (SPAD)}

The results of Table (5) showed a significant effect in most of the experimental treatments. The addition of phosphorous with an average of (270) $\mathrm{kg} \mathrm{ha}^{-1}$ was significantly superior to the other levels. The levels of addition (90, 180 and 270) gave an average of (270) $\mathrm{kg} \mathrm{ha}^{-1}$ of chlorophyll concentration reached (44.94, 47.097 and 48.67) Spad, respectively, with a significant increase of (7.93, 13.11 and 16.88) respectively compared to the no-additive treatment that gave (41.64) Spad. This increase may be attributed to the role of added phosphorus in building a strong, deep root system that contributes to the absorption of nutrients, especially nitrogen, such as increasing its concentration in the plant, which contributes to building the chlorophyll molecule and helping the roots to produce cytokinin to save chlorophyll from decomposition [24]. The addition of phosphate fertilizer to the increase in the leaf area in Table (5), which was reflected in the increase in the carbonization process. These results were in agreement with what was found by [25], who found that the addition of phosphate fertilizer averaged $\left(72,108,144\right.$ and 180) $\mathrm{kg} \mathrm{P}^{-1}$ gave a concentration of chlorophyll that reached $(48.95,52.07,55.34,55.05$ and 54.85) SPAD, while the nonaddition treatment gave an average of (48.95) SPAD.

Phosphate source had a significant effect on the concentration of chlorophyll in the ear of the leaf, as it was superior to Triple le super phosphate fertilizer and gave an average of (46.42) Spad with a percentage of $3.76 \%$ compared to the DAP treatment, which gave an average of (44.74) SPAD. The results of Table (5) indicate that the addition of sheep and compost residues gave an average concentration of chlorophyll in the earfish leaf with an average of (47.28 and 45.58) SPAD, respectively, and the non-addition treatment gave an average of (43.90) SPAD. This is due to the role of organic matter and the nutrients it contains, especially nitrogen, which plays a direct role in building the pigment chlorophyll. On the other hand, the addition of organic waste led to an increase in the leaf area of the plant, thus exposing a larger surface area of the plant to sunlight, which was reflected in an increase Chlorophyll in the leaves, these results were in agreement with what was found [8]. 
Table 5 - Effect of phosphorous source and organic fertilizer on the concentration of chlorophyll (SPAD) under different levels of phosphorous

\begin{tabular}{|c|c|c|c|c|c|c|}
\hline \multirow{2}{*}{$\begin{array}{c}\text { Type } \\
\text { organic } \\
\text { fertilizer } \\
\text { M }\end{array}$} & \multirow{2}{*}{$\begin{array}{c}\text { source of } \\
\text { phosphate } \\
\text { fertilizer } \\
\mathrm{T}\end{array}$} & \multicolumn{4}{|c|}{$\begin{array}{c}\text { Phosphor rate }\left(\mathrm{Kg} \mathrm{ha}^{-1}\right) \\
\mathrm{P}\end{array}$} & \multirow{2}{*}{ MT } \\
\hline & & $\mathrm{P}_{0}$ & $\mathrm{P}_{1}$ & $\mathrm{P}_{2}$ & $\mathrm{P}_{3}$ & \\
\hline \multirow[t]{2}{*}{$\mathrm{Z}$} & $\mathbf{T}$ & 40.101 & $43.00 \mathrm{ij}$ & $44.80 \mathrm{fhg}$ & $44.95 \mathrm{fg}$ & $43.21 \mathrm{~d}$ \\
\hline & D & $40.58 \mathrm{kl}$ & $44.48 \mathrm{hg}$ & $46.07 \mathrm{ef}$ & $47.18 \mathrm{de}$ & $44.58 \mathrm{c}$ \\
\hline \multirow{2}{*}{$S$} & $\mathbf{T}$ & $42.39 \mathrm{ji}$ & $45.33 \mathrm{fg}$ & $47.29 \mathrm{de}$ & $49.48 \mathrm{~b}$ & $46.12 \mathrm{~b}$ \\
\hline & D & $43.00 \mathrm{ji}$ & $47.51 \mathrm{~d}$ & $50.44 \mathrm{~b}$ & $52.80 \mathrm{a}$ & $48.44 \mathrm{a}$ \\
\hline \multirow{2}{*}{$\mathrm{K}$} & $\mathbf{T}$ & $42.00 \mathrm{j}$ & $43.59 \mathrm{ih}$ & $45.82 \mathrm{gf}$ & $48.20 \mathrm{~cd}$ & $44.90 \mathrm{c}$ \\
\hline & D & $41.76 \mathrm{jk}$ & $45.70 \mathrm{gf}$ & $48.16 \mathrm{~cd}$ & $49.40 \mathrm{cb}$ & $46.26 \mathrm{~b}$ \\
\hline \multirow{3}{*}{ TP } & & & & & & Average $\mathrm{T}$ \\
\hline & $\mathbf{T}$ & $41.78 \mathrm{e}$ & $45.90 \mathrm{c}$ & $48.22 \mathrm{~b}$ & $49.79 \mathrm{a}$ & $46.42 \mathrm{~A}$ \\
\hline & D & $41.50 \mathrm{e}$ & $43.97 \mathrm{~d}$ & $45.97 \mathrm{c}$ & $47.54 \mathrm{~b}$ & $44.74 \mathrm{~B}$ \\
\hline \multirow{4}{*}{ MP } & & & & & & $\begin{array}{c}\text { Average } \\
\text { M }\end{array}$ \\
\hline & $\mathrm{Z}$ & $40.34 \mathrm{i}$ & $43.74 \mathrm{~g}$ & $45.44 \mathrm{ef}$ & $46.07 \mathrm{de}$ & $43.90 \mathrm{C}$ \\
\hline & $\mathrm{S}$ & $42.70 \mathrm{~h}$ & $46.42 \mathrm{~cd}$ & $48.87 \mathrm{~b}$ & $51.14 \mathrm{a}$ & $47.28 \mathrm{~A}$ \\
\hline & $\mathrm{K}$ & $41.88 \mathrm{~h}$ & $44.65 \mathrm{f}$ & $46.99 \mathrm{c}$ & $48.80 \mathrm{~b}$ & $45.58 \mathrm{~B}$ \\
\hline \multicolumn{2}{|c|}{ Average $\mathrm{P}$} & $41.64 \mathrm{D}$ & $44.94 \mathrm{C}$ & $47.097 \mathrm{~B}$ & $48.67 \mathrm{~A}$ & \\
\hline \multicolumn{3}{|c|}{$\begin{array}{c}\mathrm{T}: \text { Triple super phosphate } \\
\mathrm{D}: \text { Di- Ammonium phosphate }\end{array}$} & $\begin{array}{l}\mathrm{P}_{0}: 0 \mathrm{kgP} \mathrm{ha}^{-1} \\
\mathrm{P}_{1}: 90 \mathrm{kgP} \mathrm{ha}^{-1} \\
\mathrm{P}_{2}: 180 \mathrm{Kg} \mathrm{P} \mathrm{ha} \\
\mathrm{P}_{3}: 270 \mathrm{Kg} \mathrm{P} \text { ha }\end{array}$ & $\begin{array}{l}Z: \Gamma \\
S: s \\
K: c\end{array}$ & $\begin{array}{l}\text { adding orge } \\
\text { p manure } \\
\text { apost }\end{array}$ & ic fertilizer \\
\hline & & & $\begin{array}{l}\text { lar letters, there } \\
\text { according to Du }\end{array}$ & $\begin{array}{l}\text { lo significa } \\
\text { an's test }\end{array}$ & Pranco & en them \\
\hline
\end{tabular}

The superiority of sheep manure over compost is due to the fact that it contains a higher amount of nitrogen (Table 2) compared to compost. The results of the binary interaction between the source and level of phosphate fertilizer showed that it was in favor of the TP3 treatment, which gave an average of (49.79) SPAD, and the 
comparison treatments TP0 and DP0 gave the lowest mean of (41.78 and 41.50) SPAD, respectively. The interaction between the source of the organic fertilizer and the level of phosphorous showed significant differences between the treatments, as the treatment SP3 gave the highest average chlorophyll concentration, which amounted to (51.14) SPAD, which was significantly superior to all treatments in this interaction, and the treatment ZP0 (without adding organic fertilizer and phosphate) gave the lowest average in this interaction. reached (40.34) SPAD. The results of Table (5) showed that the interaction between the source of organic fertilizer and the source of phosphorous was in favor of the treatment $\mathrm{SD}$, which gave the highest average of (48.44) SPAD, outperforming all treatments in this interaction, and the treatment ZT gave the lowest average In this overlap amounted to (43.21) SPAD. The interaction between the three study factors showed significant differences between some treatments if the interaction treatment SDP3 gave the highest mean (52.80) SPAD, which significantly outperformed all the treatments in this interaction, and the comparison treatments ZTP0 and ZDP0 gave the lowest mean of the two treatments. (40.10 and 40.58) SPAD, respectively.

\subsection{Corn Grain Yield $\left(\mathrm{kg} \mathrm{ha}^{-1}\right)$}

Table (6) shows the effect of phosphate and organic fertilizer source on corn grain yield under different levels of phosphorous. The table (6) shows that the increase in phosphorous levels led to an increase in the grain yield. The results for the levels $(0$, 90,180 and 270) $\mathrm{kg} \mathrm{P} \mathrm{ha}^{-1}$ are $\left(4041,5069,5990\right.$ and 6874) $\mathrm{kg} \mathrm{ha}^{-1}$, respectively, as it was observed that the yield increased by $(25.24,48.32$ and 70.11$) \%$ for the levels of addition (90, 180 and 270) $\mathrm{kg} \mathrm{P}$ ha-1, respectively, compared to the no-addition treatment. The reason for this increase in the result when the level of phosphate fertilizer is increased is due to the importance of phosphorus in the metabolic processes in the plant and thus increase the yield of grain, and on the other hand, the reason may be due to the role of phosphorus in the formation of a large radical group that has the ability to penetrate into the soil and then increase the absorption of other nutrients And to the important role of phosphorus in the formation and filling of grains [12]. These results were in agreement with [17], as well as with [19], who found that the addition of phosphorus with an average of $\left(20,40\right.$ and 60) $\mathrm{kg} \mathrm{P} \mathrm{ha}^{-1}$ The grain yield of corn was $\left(4.59,5.12\right.$ and 5.11) tons $\mathrm{ha}^{-1}$, while the comparison treatment gave a lower yield amounted to (3.08) tons ha-1. The results in tables (6) show that there is a significant effect of the source of the phosphate fertilizer added to the soil, as the differences were significant between the two sources of phosphorous. The DAP source significantly outperformed the source of TSP and achieved the highest amount of (5641) kg ha-1 with an increase of 5.52\% over the fertilizer TSP (Triple le Super Phosphate). The reason for this increase is due to the acidic effect of fertilizer on the soil, which leads to the readiness of nutrients in it, and then the increase in the yield of grain, and this is consistent with what [10] found. It agrees with what [3] found that DAP fertilizer was superior to Triple Super Phosphate fertilizer and gave the highest grain yield of corn . 
Table 6 - Effect of phosphorous source and organic fertilizer on corn grain yield $\left(\mathrm{kg} \mathrm{ha}^{-1}\right)$ under different levels of phosphorous

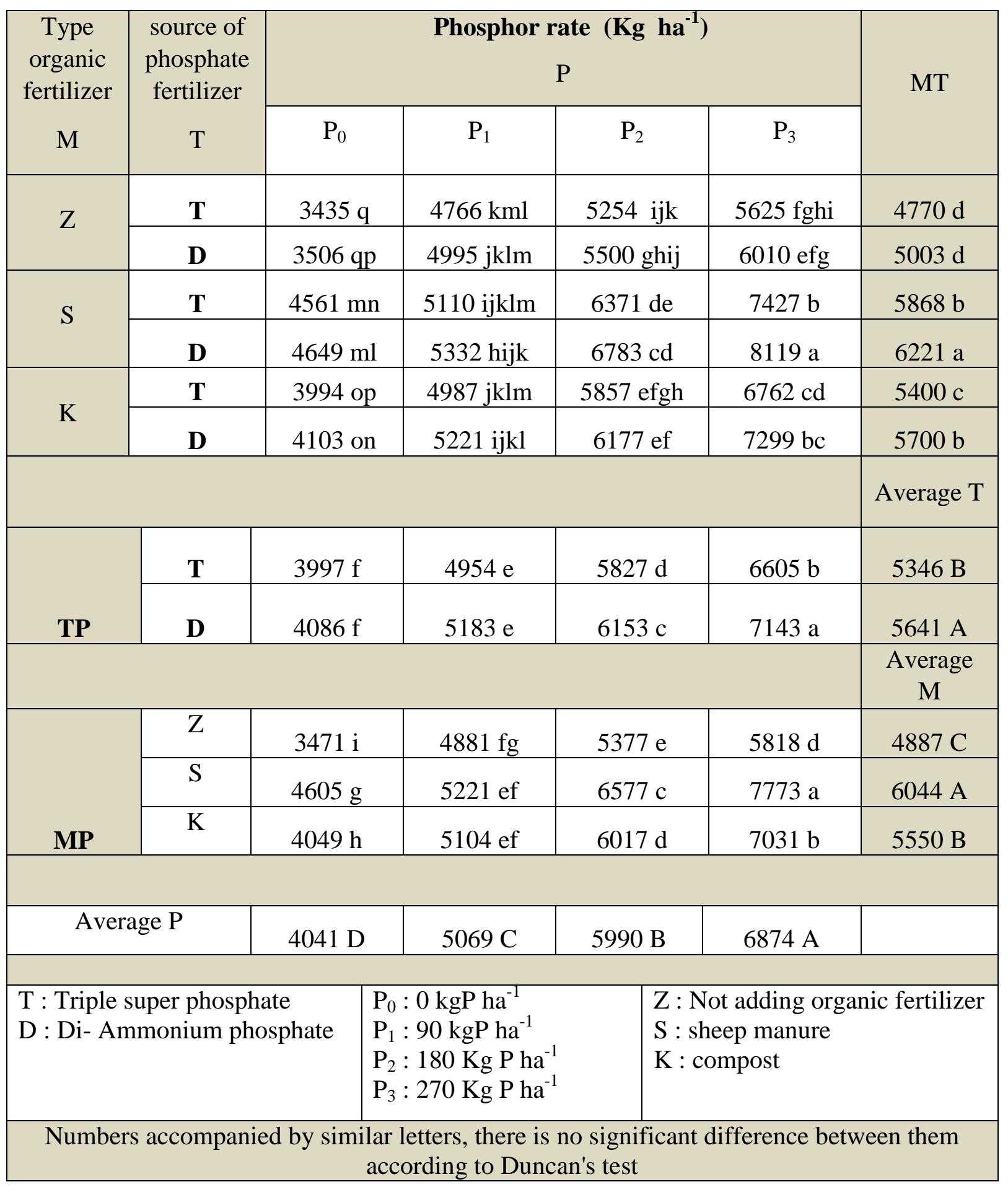

The results in Table (6) also showed a significant increase in grain yield by adding organic fertilizers, as adding sheep manure and compost achieved a grain yield of (6044 and 5550) kg ha-1, respectively, achieving an increase of (23.68 and 13.57)\% compared to the comparison treatment. $\mathrm{Z}$, whose grain production amounted to 4887 
$\mathrm{kg} \mathrm{ha}^{-1}$. The reason for this is due to the role of organic fertilizer rich in nutrients and its positive effect in improving the physical and chemical properties of the soil, which led to an increase in its fertility and an increase in the readiness of nutrients $(\mathrm{N}, \mathrm{P}, \mathrm{K})$ in Soil and then increase the quantities absorbed from it and increase the yield of grains. These results are consistent with what was indicated by [13] and [16] that the addition of organic fertilizers led to a significant increase in grain production for corn yield . It is also noted that sheep residues are superior to compost residues by $8.90 \%$, and this is due to the fact that sheep waste contains nutrients higher than table (2), and it also secreted more humic acids than corn residues, which led these acids to reduce the $\mathrm{pH}$, and then increased the availability and availability of nutrients to the plant And then it was reflected in the situation. The results of the binary interaction between the source and level of phosphate fertilizer show that it was in favor of treatment DP3, which gave a yield of (7143) $\mathrm{kg}$ ha-1, and the comparison treatments TP0 and DP0 gave a yield of (3997 and 4086) $\mathrm{kg}$ ha-1, respectively. The interaction between the source of the organic fertilizer and the level of phosphorous showed significant differences between the treatments, as the treatment SP3 gave the highest grain yield amounted to (7773) $\mathrm{kg}$ ha-1, and the treatment ZP0 (without adding organic fertilizer and phosphate) gave the lowest average in this interaction reached (3471) $\mathrm{kg} \mathrm{ha}^{-1}$. The results of Table (6) showed that the interaction between the source of organic fertilizer The source of phosphorous was in favor of the SD treatment, which gave the highest mean of (6221) $\mathrm{kg}$ ha-1, superior to all treatments in this interaction, and the ZT treatment gave the lowest average of (4770) $\mathrm{kg}$ ha-1, which did not differ significantly from the ZD treatment. The interaction between the three study factors showed significant differences between some treatments if the interaction treatment SDP3 gave the highest mean of (8119) $\mathrm{kg}$ ha-1, significantly superior to all treatments in this interaction, and the comparison treatments ZTP0 and ZDP0 gave the lowest average of (3435 and 3506) $\mathrm{kg} \mathrm{ha}^{-1}$, respectively.

\section{Conclusions}

1-Sheep manure outperformed compost in the characteristics of (dry weight, the concentration chlorophyll in the leaves and Grain yield of corn).

2-The superiority of DAP fertilizer over TSP fertilizer in all studied traits.

3-The application (270) $\mathrm{kgP} \mathrm{ha}^{-1}$ in all the studied traits.

\section{References}

[1] Al- Barzanji, A. F., Paliwal, K.V. Al-Karagholi, R.A.D. and Al-Abbas, H.A0 1980 OResponse of wheat crop to fertilizers (N.P.K) on the gypsiferous soils of Al Dour region. SOSLR, research center for gypsiferous soils . Tech. Bull.No.1 .Iraq.

[2] Al-Barzanji, Z. M,. 2006. The critical period for weed control in corn (Zea myas L.). Master Thesis . faculty of Agriculture . Baghdad University. 
[3] Al-Jumaili, AW, AR,. and Jassim.R.A,. 2014. Effect of phosphorous source and methods of adding chelated zinc on growth and yield of corn plant. AlMuthanna Journal of Agricultural Sciences. 2 (1):1-11.

[4] Black, C.A. 1965 a. Methods of soil analysis. Part1. Physical and Mineralogical properties Am. Soc. Agron., 9.Madison,Wisconsin,USA.

[5] Bremner ,J.m .and C.S. Mulvaney. 1982. Nitrogen total. In A.L.(ed.) ,Methods of soil analysis. Agron Chemical and Microbiological properties, $2^{\text {nd }}$ Ed., Am .Soc. Agron WI,USA.NO:9 Part(2):595-624

[6] Havlin, J.L., J.D. Beaton, S.L. Tisdale, and W.L. Nelson. 2005. Soil Fertility and Nutrient Management. 7th Edition. Pearson Prentice Hall. Upper Saddle River, NJ.

[7] Jackson, M.L. 1958. Soil Chemical Analysis. Prentice-Hall. Inc. Engelwood. Cliffs , N.J.

[8] Khalifa, K. M., Saeed,M.F., and Al-Mosili,M.A,. 2017. Effect of organic and chemical fertilization on the growth and yield of corn (Zea mays L.) grown in gypsum soil. Tikrit Journal of Agricultural Sciences. Proceedings of the Sixth Scientific Conference on Agricultural Sciences: 596-611.

[9] Lagerwerff, J.V, G.W.A Kin., and . S.W.Moses. 1965. Dectection and determination of gypsum in soils. Sci.Soc. Am. Proc.29 (35540).

[10] Majeed, M. A, R, Ahmad, M.Tahir, A,Tanveer and M, Ahmad .2014. effect of phosphorus fertilizer sources and rates on growth and yield of wheat (Triticum aestivum L.). Asian J Agri Biol. 2(1):14-19.

[11] Majidian M., Ghalavand A., Karimian N., Kamkar, Haghighi, A.2006. Effects of water stress, nitrogenfertilizer and organic fertilizer in various farming systems in different growth stages on physiological characteristics, physical characteristics, quality and chlorophyll content of maize single cross hybrid 704. Iranian Crop Sciences, J. 10(3): 303-330.

[12] Matar , A. E. (1977). yield and response of cereal crop to phosphorus fertilization under changing rainfall condition .Agron. J . (69): 879-881.

[13] Mbah.,C,N. and E.U. Onweremadu. 2009. Effect oforganicand mineral fertilizer inputs on soil and maize grain yield in acid ultisols in abakalikisouthEastren Nigeria.American-Eurasian J. of Agr. 2(1):7-12.

[14] Mengel, K. and E.A. Kirkby. 1982. Principles of plant nutrition. International Potash Institute. Bern, Switzerland.

[15] Mengel, K., and E. A. Kirkby. 2001. Principles of plant nutrition. $5^{\text {th }}$ ed. Intern. Potash Inst., Bern, Switzerland.

[16] Mohammed,T.2019. Effect of Organic and Inorganic Fertilizers on Yield of Maize in Mubi North Local Government Area, Adamawa State, Nigeria. International Journal of Innovative Agriculture \& Biology Research 7(2):26-35. 
[17] Muhawish N. M. and Razaq I. B. 2009. Agronomic Effectiveness of a New Formula of Phosphate Fertilizer I - Initial Agronomic Effectiveness. Journal of tikrit university for Agricultural sciences . 9 (2):617-625.

[18] Olsen, S. R., C. V. Coles, F. S. Watanabe, and L. A. Dean. 1954. Estimation of available phosphorus in soil by extraction with sodium bicarbonate. USDA. 939.

[19] Onasanya,R.O Aiyelari,. O.P Onasanya,. A Oikeh,. S Nwilene. F.E. and . Oyelakin O.O .2009. Growth and Yield Response of Maize (Zea mays L.) to Different Rates of Nitrogen and Phosphorus Fertilizers in Southern Nigeria. World Journal of Agricultural Sciences 5 (4): 400-407.

[20] Page, A.L., R.H. Miller and D.R. Kenny (1982). Method of soil analysis part (2) $2^{\text {nd }}$. ed. Agrnomy series 9. Amer. Soc of Agron Madison. Wisconsin potassium in Soil : Amini review . chemi . Int ., 2 (1) : 58 -69.

[21] Pratt, P. F. 1965. Potassium . ( In C. A. Black Ced ) Methods of soil analysis . Agronomy 9: 1022-1030. Am .Soc. Agron Madison, Wis.

[22] Richards, L. A. 1954 . Diagnosis and improvement of saline and alkli soil. U.S. D. A. Handbook No-60

[23] Tisdale, S. L., W. L. Nelson, J. L. Havlin. 1997. Soil Fertility and Fertilizers. Prentice Hall of India, New Delhi topics No: 4. International potash inst. Bern .P : 7- 9 .

[24] Tollenaar, M.A. and J.Wu . (1999). Yield improvement in temperate maize is attribute to greater stress tolerance. Crop Sci. 39 : 1597-1604.

[25] Xin-kai,Z. Chun-yan,L.I. Zong-qing,J. Lian-lian,H. Chao-nian,F. Wen-shan,G andYong-xin,P.2012. Responses of Phosphorus Use Efficiency, Grain Yield, and Quality to Phosphorus Application Amount of Weak-Gluten Wheat. Journal of Integrative Agriculture. 11(7): 1103-1110.

[26] Zafar,M,M.K.Abbasi,A,Khaliq and Z.ur-Rehman.2011.Effect of Combining materials with inorganic phosphorus sources on growth, yield,energy content and phosphorus uptake in maize at Rawalakot Azad Jammu and Kashmir, Pakistan. Applied Science Research,3(2):199-212. 